\title{
Canal Istanbul and Political Dispute on Turkish Straits
}

\author{
Ceyhun ÖZÇELİK ${ }^{1}$, Kader BENLi ${ }^{*}$ \\ ${ }^{1}$ Muğla Sitkı Koçman University, Civil Engineering Department, cozcelik@mu.edu.tr, Orcid No: 0000-0003-4111-2562 \\ ${ }^{2}$ Ege University, Civil Engineering Department, PhD Candidate, kaderbenli48@gmail.com, Orcid No: 0000-0002-7768-6317
}

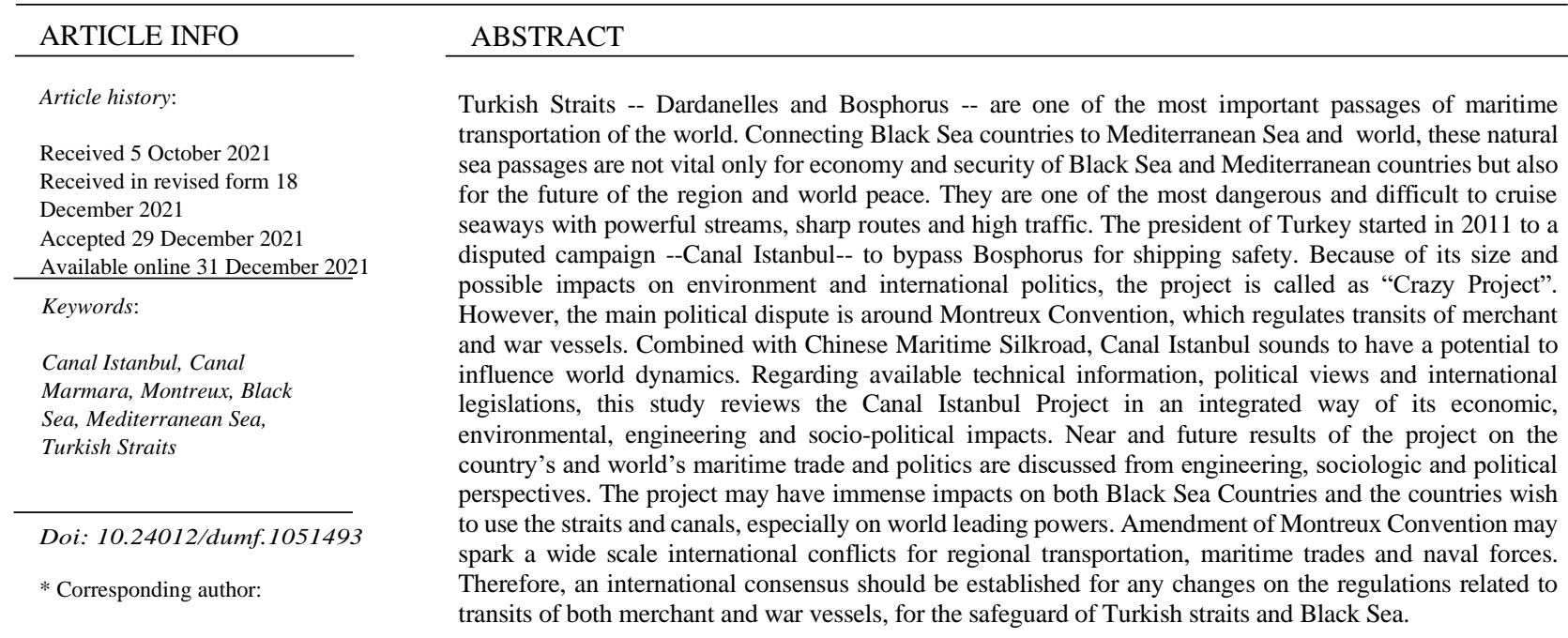

\section{Introduction}

Upon China's being world's economic leader in 2014 based on purchasing power [1] and together with fluctuations on global power balances, the importance of global waterways has begun to increase, especially by the effects of Silk Road Economic Belt and Maritime Silk Road initiatives which has started by Chinese leader Xi Jinping in 2013. The first practical step of these initiatives was Belt \&Road Forum for International Cooperation -- $21^{\text {th }}$ Century's Silk Road--. This step brought together high-level authorities from many countries including Turkey's president Recep Tayyip Erdogan, heads of states of Russia, Hungary, Mongolia and Tajikistan.

On the success of these initiations one of the important roles of Turkey's political pose, regarding its geostrategic location and historical connections. Vessel traffic of Asia through Bab al Mandab and Suez Canal, oil tankers of Hurmuz strait (Umman Bay), merchant and war vessels of Gibraltar (Cebelitarık) Strait, ships of Black Sea and trades via Caspian Sea intersect in the region. Such a geostrategic importance keeps region dynamic as well as under stress. However, the flaring dispute was not until Turkish President declaration on Istanbul Strait on April 27, 2011. His campaign was on constructing an artificial canal named -- Canal Istanbul-- to bypass Bosphorus. Dividing Istanbul into three parts with a main island isolated by Bosphorus and Canal Istanbul, the project in fact aims a safe maritime transportation along Bosphorus. In the strategic plan of Turkey's Ministry of Transportation and Infrastructure for 2019-2023, this aim was given as "to create an international water way to reduce traffic in Bosphorus." [2] The Project is also expected to increase revenues from transits and navigation through Turkish straits.

The canal draws large public controversy, reviving periodically. One of the main discussions is economical dimension of the project. It changes between 10 to 80 billion USD, depending on facilities to be considered. if the project will return its investment is unclear. The project has a potential to generate a migration pressure on Istanbul with 0.5 to 1.5 million new habitants. During the construction period, population of central Istanbul is to be stacked in a narrow island.

Environmental concerns include but not limited with million tons of rubble, losses of already limited farm and green areas, contamination of fresh water resources, unplanned increase in population, deformation of costal zones and degradation of flora and fauna habitats. Therefore, the critical question raised by opposition parties is if it is worthy to trench the city from end to end at the cost of million dollars so as to provide an alternative and safe passage for transits through straits. The reactions around the country are different, and people seems to be divided into 
two opposite opinions. Is it a vision to lead the country to future or a ravage dividing Istanbul into three parts by wasting billions of dollars for vain?

The main text regulating transit and navigation in Turkish straits is Montreux Convention. It recognizes the freedom of transits without any formality except some service charges and taxes. It is still in force for 83 years, since the date of its entry into force on December 11, 1936. Therefore, diverting the navigation from a natural strait into a narrow Canal subjected to a fee collection sounds a problematic issue. In fact, Montreux Convention would have been in force for 20 years after the registration of the Convention in 1936. However, since no High Contracting Party have given any notice of denunciation, it is still continuing in force, and will be continuing in force until two years after such notice shall have given. If Canal Istanbul will prompt the contracting parties to give such any notice?

This study aims to review technical information, political views and international legislations on economic, environmental, socio-politic aspects of the Canal Istanbul Project. Project's future impacts on maritime transportation, regional and international peace as well as on the safety of Bosphorus and Istanbul is discussed. The project is also evaluated regarding alternative routes from Aegean Sea to Black Sea, considering Montreux Convention, which comprises not only Bosphorus but also Dardanelles as well as Black Sea.

\section{Study Area}

\section{Istanbul \& Straits --Bosphorus \& Dardanelles-}

Istanbul is the city at the intersection of two continents -Asia and Europe--. Bosphorus is the passage dividing
Istanbul into two parts, connecting Black Sea to Aegean Sea through Marmara Sea and Dardanelles. The length of the strait is $30 \mathrm{~km}$, the width is $700 \mathrm{~m}$ at the narrowest section and $3600 \mathrm{~m}$ at the largest section. Its maximum depth is 120 $\mathrm{m}$. There are three suspension bridges over Bosphorus, which are 15 Temmuz Şehitler, Fatih Sultan Mehmet and Yavuz Sultan Selim Bridges. There is a channel tunnel under the Bosphorus, making possible to connect Beijing to Londan. Bosphorus is the only passage to reach to Mediterenian Sea and thus to oceans, for Black Sea countries -- Ukraine, Romania, Bulgaria, Georgia and Russia --

Dardanelles is the only passage connecting Mediterranean Sea to Marmara Sea then to Black Sea. The largest settlement along the coast of Dardanelles is Canakkale city with a population of 540000. The length of Dardanelles is $61 \mathrm{~km}$, and the width is $1.2 \mathrm{~km}$ at minimum and $7 \mathrm{~km}$ at maximum. The deepest point of the strait is $103 \mathrm{~m}$.

The population of Istanbul is 15.07 million and the largest of Turkey, with the density approximately 2840 person $/ \mathrm{km}^{2}$. Water resources of Istanbul fall short of the water demand. Having clean-fresh water in the city is getting more and more difficult, parallel to increase in urbanization [3]. Table 1 shows available water resources supplying water to the city. Sazlidere Dam, which is to be removed by Canal Istanbul Project, supplies $3.3 \%$ of the water requirement. Waters of Terkos Lake, which is under the risk of contamination by saline waters of the Canal, supplies $8.6 \%$ of water requirement. 65 percent of this population lives in European side of the city while the only $35 \%$ of fresh waters is available there [4].

Table 1. Fresh water resources of Istanbul

\begin{tabular}{|c|c|c|c|c|c|c|c|c|c|c|c|c|c|c|c|c|c|}
\hline \multirow[b]{2}{*}{ 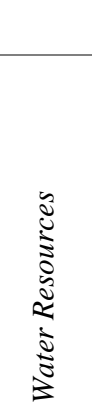 } & \multicolumn{8}{|c|}{ Anatolia } & \multicolumn{8}{|c|}{ Europe } & \multirow[b]{2}{*}{ 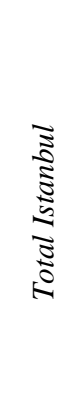 } \\
\hline & 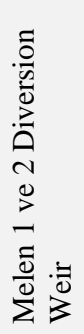 & 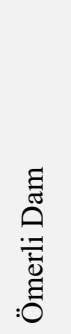 & 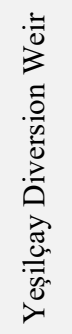 & 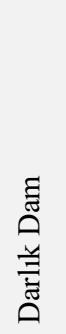 & 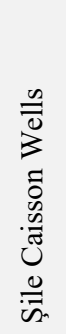 & 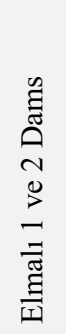 & 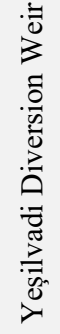 & 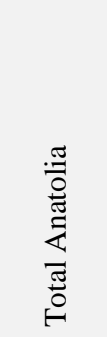 & 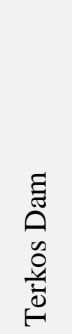 & 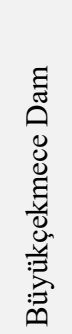 & 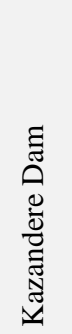 & 氮 & 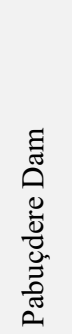 & 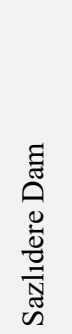 & 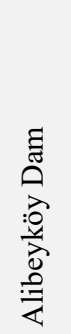 & 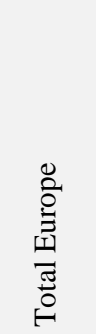 & \\
\hline $10^{6} \mathrm{~m}^{3}$ & 575 & 220 & 145 & 97 & 30 & 15 & 10 & 1092.0 & 142 & 100 & 100 & 75 & 60 & 55 & 36 & 568.0 & 1660 \\
\hline$\%$ & 34.6 & 13.3 & 8.7 & 5.8 & 1.8 & 0.9 & 0.6 & 65.8 & 8.6 & 6.0 & 6.0 & 4.5 & 3.6 & 3.3 & 2.2 & 34.2 & 100 \\
\hline
\end{tabular}

Marmara Sea system is a semi closed sea system. Its surface area is $11500 \mathrm{~km} 2$ and its maximum depth is $1270 \mathrm{~m}$. Flow regime of Marmara Sea is from the east to west, contrary to circular type currents commonly seen on sea surfaces due to Coriolis effect [5]. Reverse currents due to coastal bathymetry and seasonal currents due to wind and pressure changes are also observed [6].
The flow regime of Marmara Sea surface is uniform because of high level Black Sea waters. Marmara Sea surface and bottom are formed by different water masses. The surface is sourced by Black Sea waters while the bottom is sourced by Aegean Sea waters. Therefore, salinity, temperature and dissolved oxygen are different in these water masses [6,7]. Black Sea waters are of low 
salinity and high oxygen. It is $40 \mathrm{~cm}$ higher than Marmara Sea. Thus, Black Sea waters flows from surface to Marmara Sea and then to Aegean Sea [8]. Contrary, Aegean Sea waters are of high salinity and low oxygen. It flows from bottom to Marmara and then to Black Sea. Figure 1 depicts annual mean flows in Marmara Sea. Data of [7] were used to get the maps in the figure.

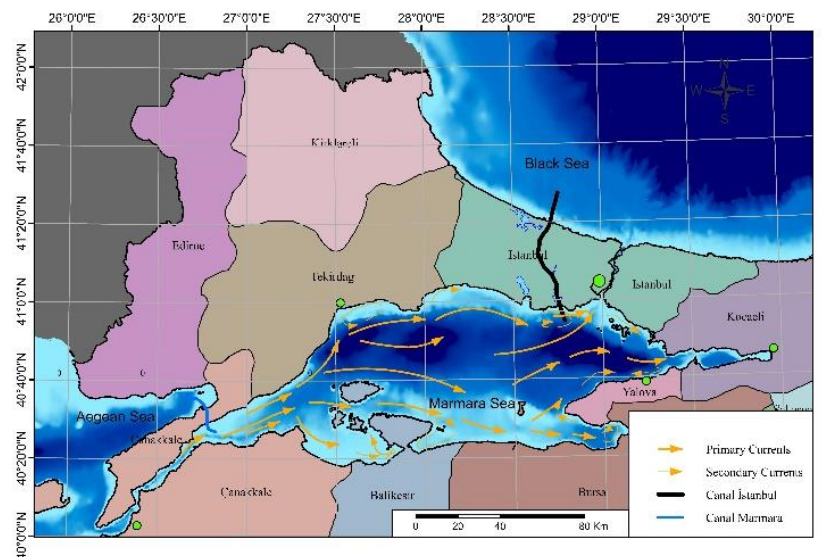

Figure 1a. Sea currents of Marmara bottom (lower).

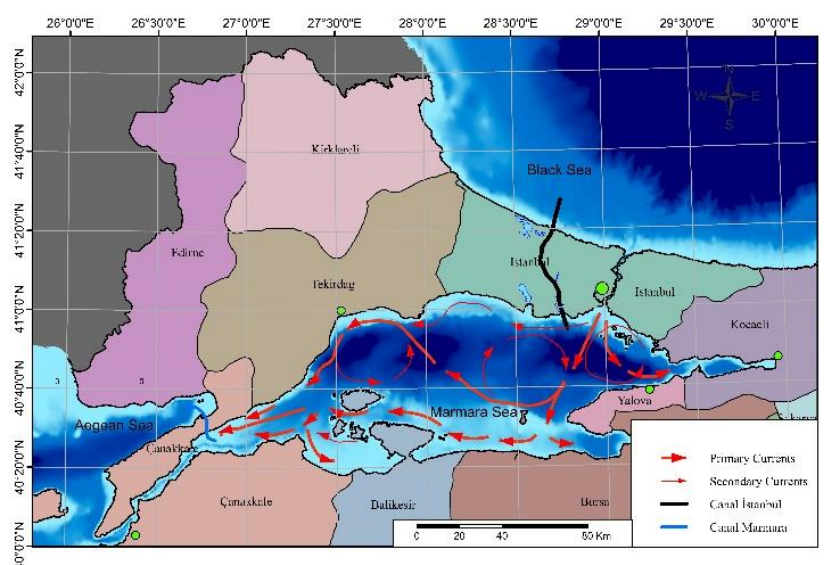

Figure 1b. Sea currents of Marmara; surface (upper).

\section{Canal Istanbul}

There were some draft ideas on connecting Black Sea and Marmara Sea during Ottoman times and also that there was a political promise of constructing such a channel during the election of 1990's Turkey. However, the declaration on April 27, 2011 about Canal Istanbul was the first serious suggestion presented to public opinion. The project was named as "Crazy Project" by public, regarding size of construction works, its constructability and its necessity [9].

Canal Istanbul bypasses Bosporus to provide a safe shipping for transits. The strategic plan of Turkey for 2019 to 2023 explain this aim as "to create an international water way in order to reduce the traffic along Bosphorus" [2]. Of a great importance for safety and economy of the Black Sea countries, Bosphorus is the main sea passage connecting Mediterranean Sea to Black Sea. This makes the strategic value of Canal Istanbul is more obvious [10]. Istanbul as well as Bosphorus and Canal Istanbul is on a location crossing continents so it is a natural part of a Silk Road, thus one of main potential partners of Silk Road Economic Belt and Maritime Silk Road Projects.

Vessels transiting Bosphorus are about 50000 in number and 365 million tonnes in cargo weight. It is expected to reach 65000 and 480 million tonnes in 2030, 95.000 and 800 million tonnes in 2050 and 115000 and 1000 million tonnes in 2070 [11]. Total number of transits along Bosphorus was around 3000 when Montreux Convention was signed in 1936 during when the population of Istanbul was approximately 800 thousand.

The number and tonnages of ships passing through Bosphorus, Gelibolu and Suez along years are given in Figure 2. Data is obtained from The Ministry of Transportation [12] and Infrastructure, and from Suez Canal Authority [13]. Regarding that today's ship traffic is about 17000 for Suez Canal and 13500 for Panama Canal, one can see that transits of Bosphorus are so high and risky as to endanger the city of Istanbul, noting daily 2500 ferryboats crossing these transits.

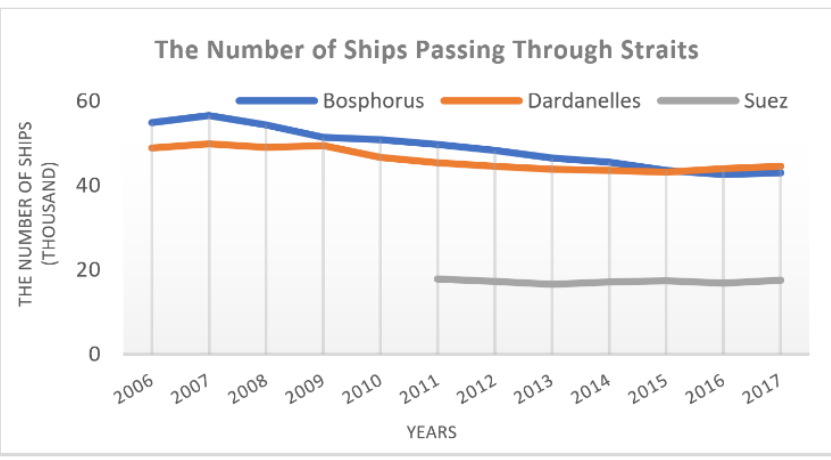

Figure 2a. Number of ships passing through Bosphorus, Dardanelles and Suez.

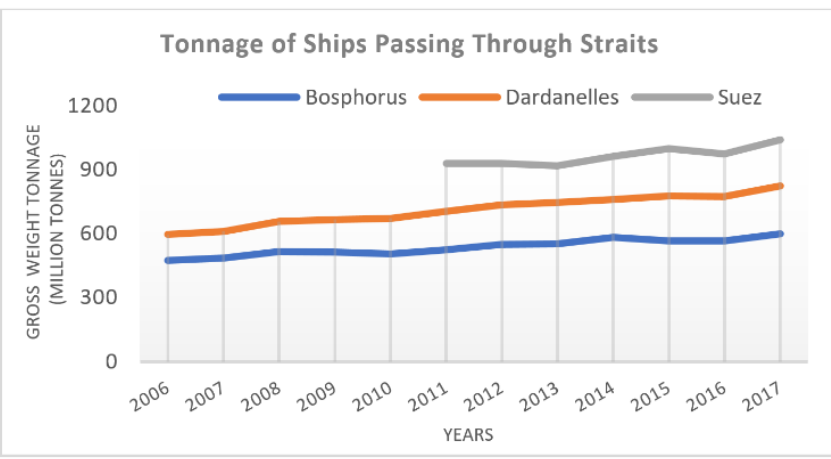

Figure 2b. Tonnages of ships passing through Bosphorus, Dardanelles and Suez.

Prepared by Ministry of Transport, Maritime Affairs and Communication in 2017, the Preliminary Report For The Environmental Impact Assessment of Canal Istanbul [11] is the first concrete effort for the Canal. The report suggests one out of the five alternative routes for Canal Istanbul. The suggested site (Figure 3) encloses Avc1lar, Kucukcekmece, Basaksehir and Arnavutkoy districts. 


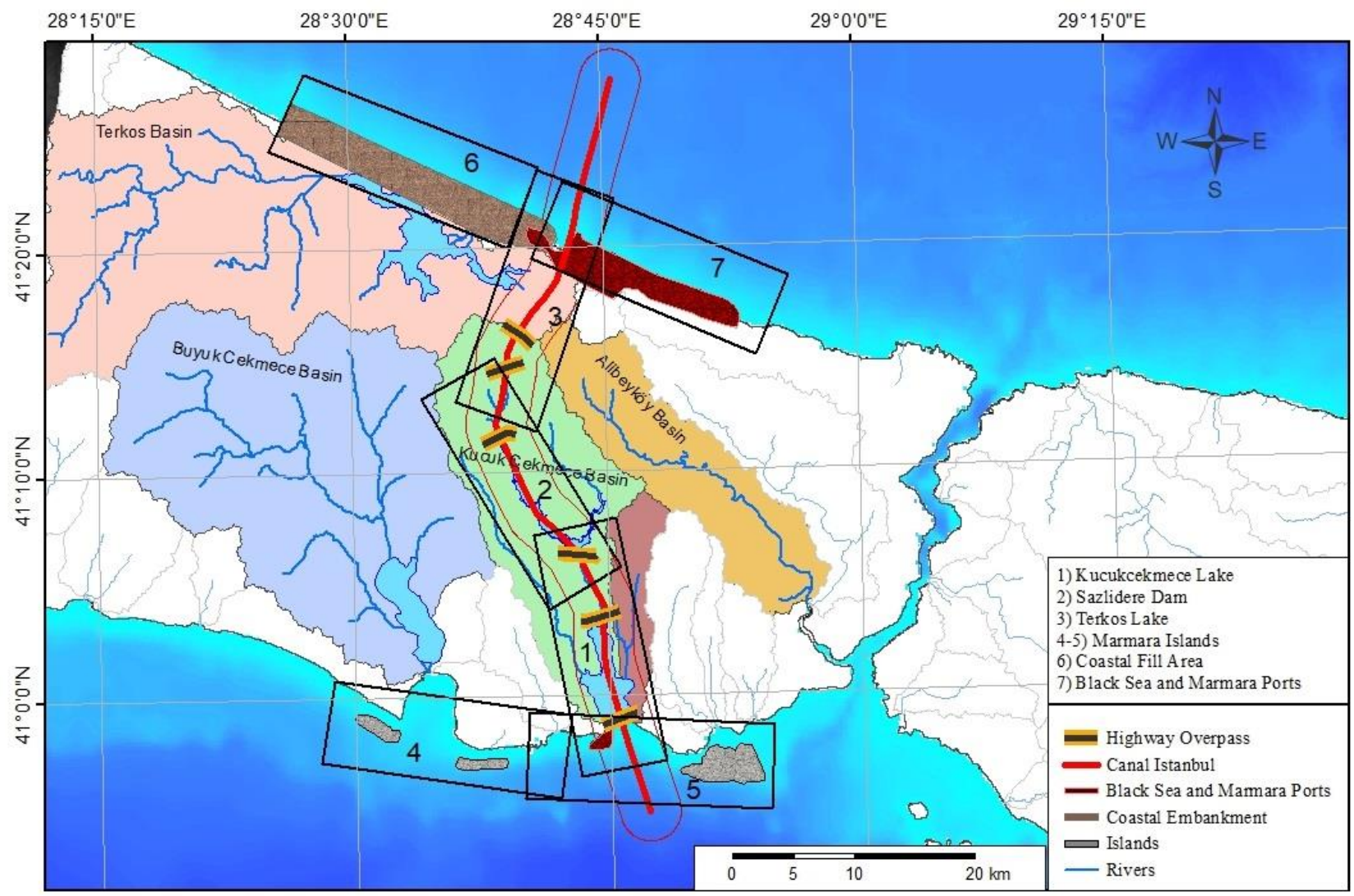

Figure 3. Canal Istanbul route map.

Black Sea entrance of Channel Istanbul is located between Terkos Lake and Istanbul new airport. Following the Sazlidere Dam, which is planned to be removed by the project, the canal reaches to Kucukcekmece Lake and then to Marmara Sea. The length of the canal is around $45 \mathrm{~km}$, the width is $250 \mathrm{~m}$ to $1000 \mathrm{~m}$, changing along the route. The depth of the canal is $25 \mathrm{~m}$, allows container ships with maximum dimensions of 145000 DWT, $275 \mathrm{~m}$ length, 48m width and $17.2 \mathrm{~m}$ draft height, and allows oil tankers with maximum dimensions of 120000 DWT, 340m length, $48.2 \mathrm{~m}$ width and draft height $15 \mathrm{~m}$ [11].

The project promises building of two new cities on both sides of the Canal. It involves Kucukcekmece Marina, Sazlidere Marina, Marmara container port and Karadeniz container port. Six bridges or overpasses are planned along the Canal. On the Black Sea side of the Canal in Catalca and Arnavutkoy districts, two coastal zones are planned for backfilling. Three groups of islands were initially planned to be created on the Marmara Sea, using the rubbles of canal excavation of 1.5 billion $\mathrm{m} 3$ and the bottom dredging of 115 million $\mathrm{m} 3$. Construction time was estimated as 5 years, in addition to a preparation time for 1 year. It is assumed that the canal would serve for 100 years [11].

Parallel to progress in planning processes, the project has undergone important revisions. The Ministry of Environment and Urbanization declared on October 2019 that the project would be realized with some revisions. With respect to this new case, the preparation time increases to 2 years. Artificial islands and Sazlıdere Marina are canceled, due to economic and environmental concerns. 1.079 billion $\mathrm{m} 3$ excavation work and 76.4 million $\mathrm{m} 3$ bottom dredging are reported. The backfilling on the Black Sea side of the Canal is 54.6 million $\mathrm{m} 3$. One of the two cites planned will be built till 2023. The cities of total 453 million $\mathrm{m} 2$ comprises of 167 million $\mathrm{m} 2$ land parcels, 108 million $\mathrm{m} 2$ roads, 30 million $\mathrm{m} 2$ canal and 37 million $\mathrm{m} 2$ green areas. The cost is revised up to 75 billion TL (12.74 billion $\$$ ). 8 to 10 thousand people is planned to work on this huge construction, spreading over an area 63.2 million $\mathrm{m} 2$ [9]. While the population to reside in these cities was reported initially as 1.2 million in total, it was revised to 500 thousand to reduce negative impacts on environment. The Minister of Environment and Urbanization stated that the cities would be smart cities with low story buildings.

\section{Canal Marmara}

Despite the disputes over Canal Istanbul Project, Turkey administration insists on Canal Istanbul, using his political power. Such an action would mean that Montreux convention may be opened into discussion in near years. Ignoring weather, the project is really to be realized or the convention is to be discussed, and without considering the consequences that the future of the region does face, should Canal Istanbul be constructed, it seems to trigger another crazy action. This action might be a launch of new canal project on Gallipoli --Canal Marmara-- which is to bypass Dardanelles, as a next step of Canal Istanbul. 
Of course, such a second channel technically is not needed and sounds an irrational action built upon a crazy action. However, depending on the future of Montreux Convention, Canal Marmara in addition to Canal Istanbul will provide full control over navigation through straits. In other words, Canal Istanbul alone does not provide a bypass route for transits along straits, since Montreux Convention encompasses not only Bosphorus but also Marmara Sea and Dardanelles.

The number and tonnage of vessels transiting Dardanelles for 2017 are 44615 and $823460636 \mathrm{gt}$, which are higher than those transiting Bosphorus -- 42978 and 599324748 gt [12]. Of the width varying between $1.2 \mathrm{~km}$ and $7 \mathrm{~km}$ along the $61 \mathrm{~km}$ length and the sparsely populated settlements on both sides, Dardanelles imposes lesser risk to navigation safety than Bosphorus. In fact, the number of transits through the straits are getting lower along the years while tonnages are increasing (Figure 4)

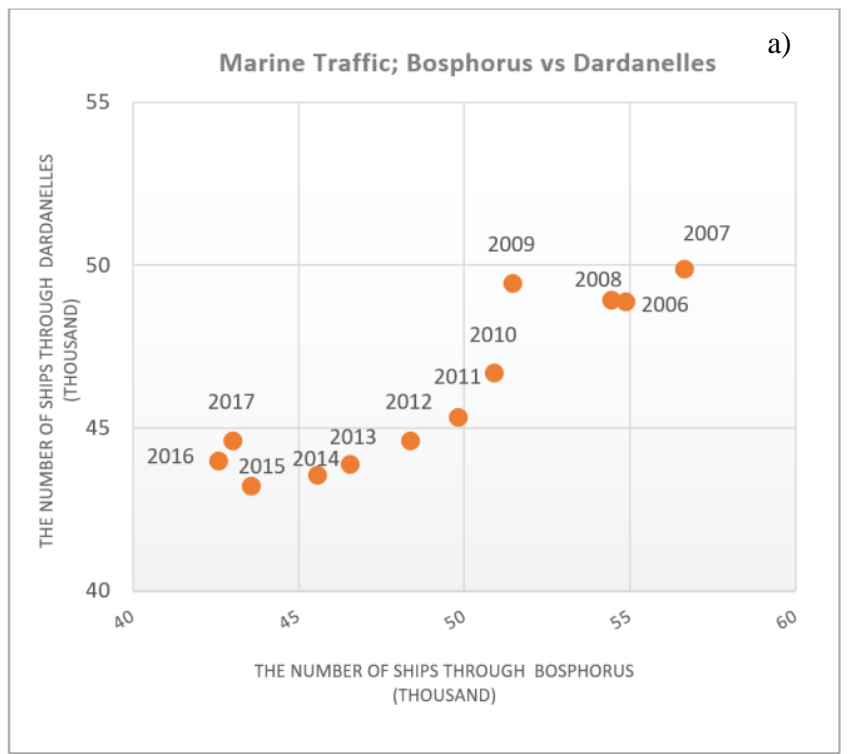

Figure 4. Comparison of transits thought Turkish straits; (a) the number of ships, (b) tonnage.
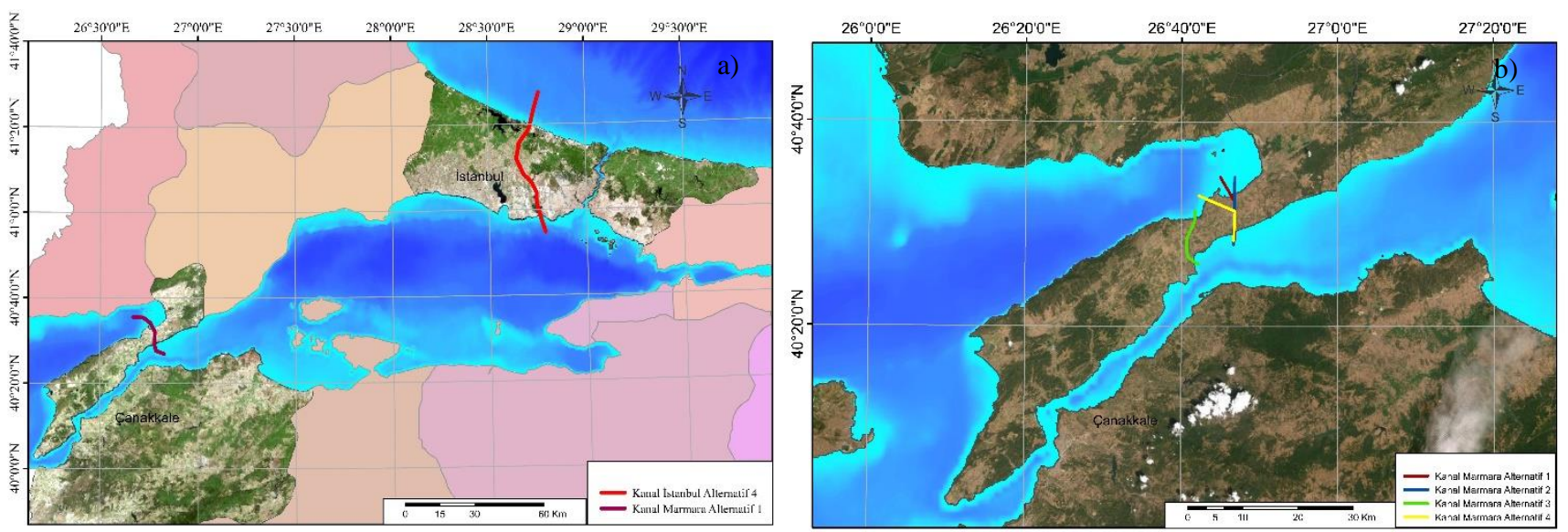

Figure 5. Canal Istanbul and Canal Marmara; (a) locations, b) alternative routes for Canal Marmara. 


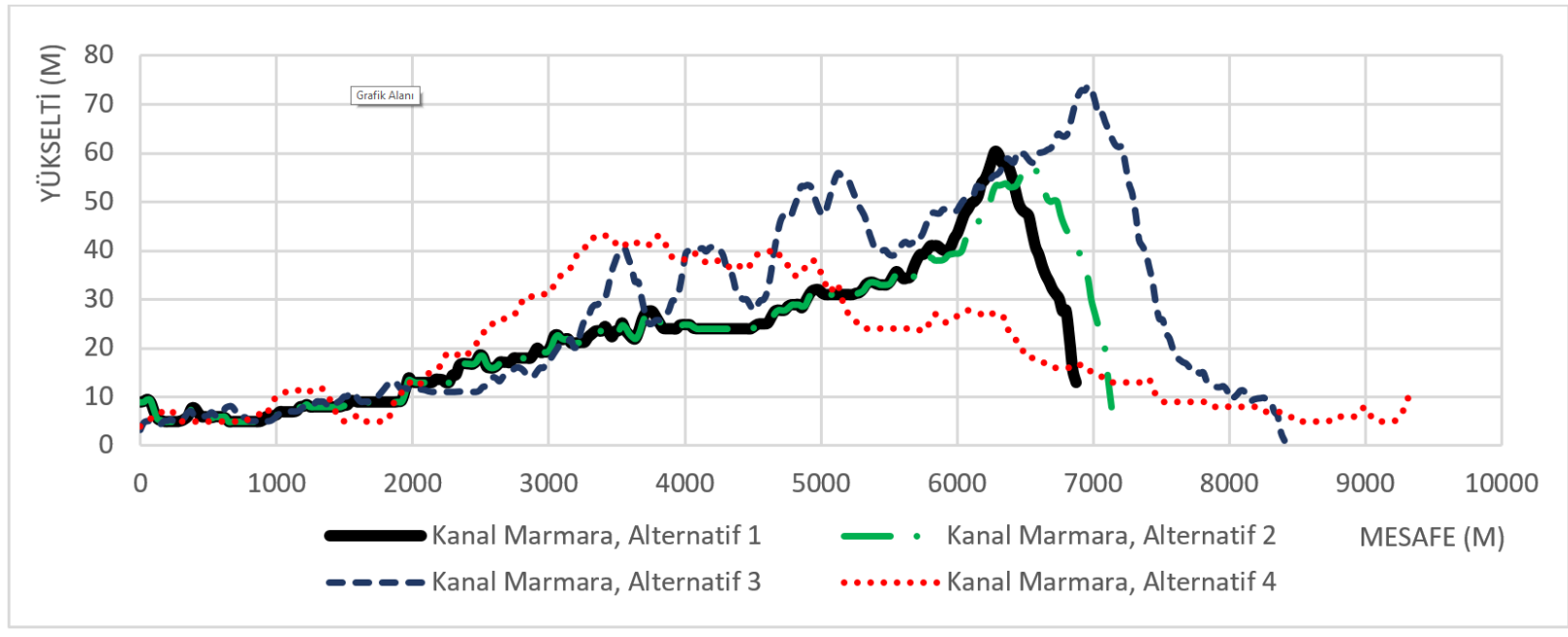

Figure 6. Cross-sections of alternative routes for Canal Marmara.

Table 2. Comparison of alternatives of Canal Marmara based on Canal Istanbul.

\begin{tabular}{c|cccccc} 
No & Canal Alternatives & $\begin{array}{c}\text { Length } \\
(\mathrm{m})\end{array}$ & $\begin{array}{c}\text { Area } \\
(\mathrm{m} 2)\end{array}$ & $\begin{array}{c}\text { Volume } \\
(\mathrm{m} 3)\end{array}$ & $\begin{array}{c}\text { Areal ratio } \\
(\%)\end{array}$ & $\begin{array}{c}\text { Volumetric ratio } \\
(\%)\end{array}$ \\
\hline 1 & Canal Istanbul Alternative 4 & 43179 & 9427500 & 236858906 & 1 & 1 \\
2 & Canal Marmara Alternative 1 & 6877 & 1521250 & 35162031 & 0.16 & 0.15 \\
3 & Canal Marmara Alternative 2 & 7131 & 1583125 & 37914688 & 0.17 & 0.16 \\
4 & Canal Marmara Alternative 3 & 8404 & 1828750 & 53642188 & 0.19 & 0.23 \\
5 & Canal Marmara Alternative 4 & 9370 & 2048125 & 40628594 & 0.22 & 0.17
\end{tabular}

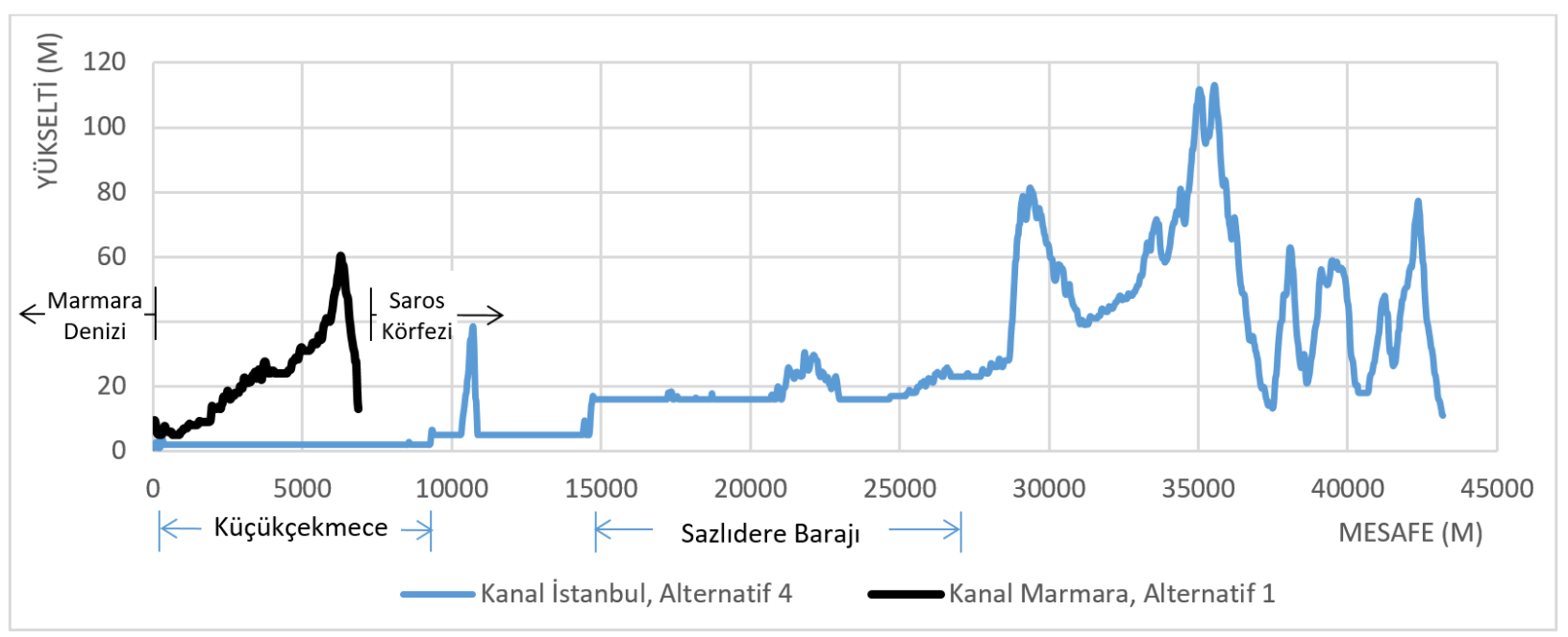

Figure 7. Canal Istanbul vs Canal Marmara

\section{Political \& Economic Aspects of the Canal Projects}

World's maritime transport rose 11 billion tons in 2018 [1], before the pandemic of corona virus. This is over $80 \%$ of the world's trade [14]. This importance on world's economy is well known so that international waterways attract special consideration around world. From this point of view, One Belt One Road project declared in 2013 to revive the old-known "Silk Road" have heated discussions on world's economic balances and trades. One Belt One Road Project -- Silk Road Economic Belt and Maritime Silk Road initiatives-- are expected to reshape the international trade and shipping industry, opening or upgrading international trade routes. It is expected to spread on over 3 continents, 66 countries, $60 \%$ of the world's population, trillion dollars of gross domestic products and $1 / 4$ of world trades. Focusing maritime trades, Maritime Silk Road aims 
alternative cheaper sea routes for shipping products to/from Central Europe from/to Central Asia, by changing the pattern of global ownership and control of infrastructure to facilitate new trade movements.

From this aspect and beyond, Canal Istanbul is at a highly strategic location. Its geostrategic importance makes these crazy actions more arguable, especially when historical, ethnic and religious roots of Turkey are considered. Its location is inside a region connects Asia and South East Asian countries to Europe and European countries to Asia and Africa (Figure 8) via Bab al Mandab and Suez Canal, Hurmuz Strait, Cebelitark Strait, Don Volga Channel, Dardanelles and Bosphorus (Figure 8)

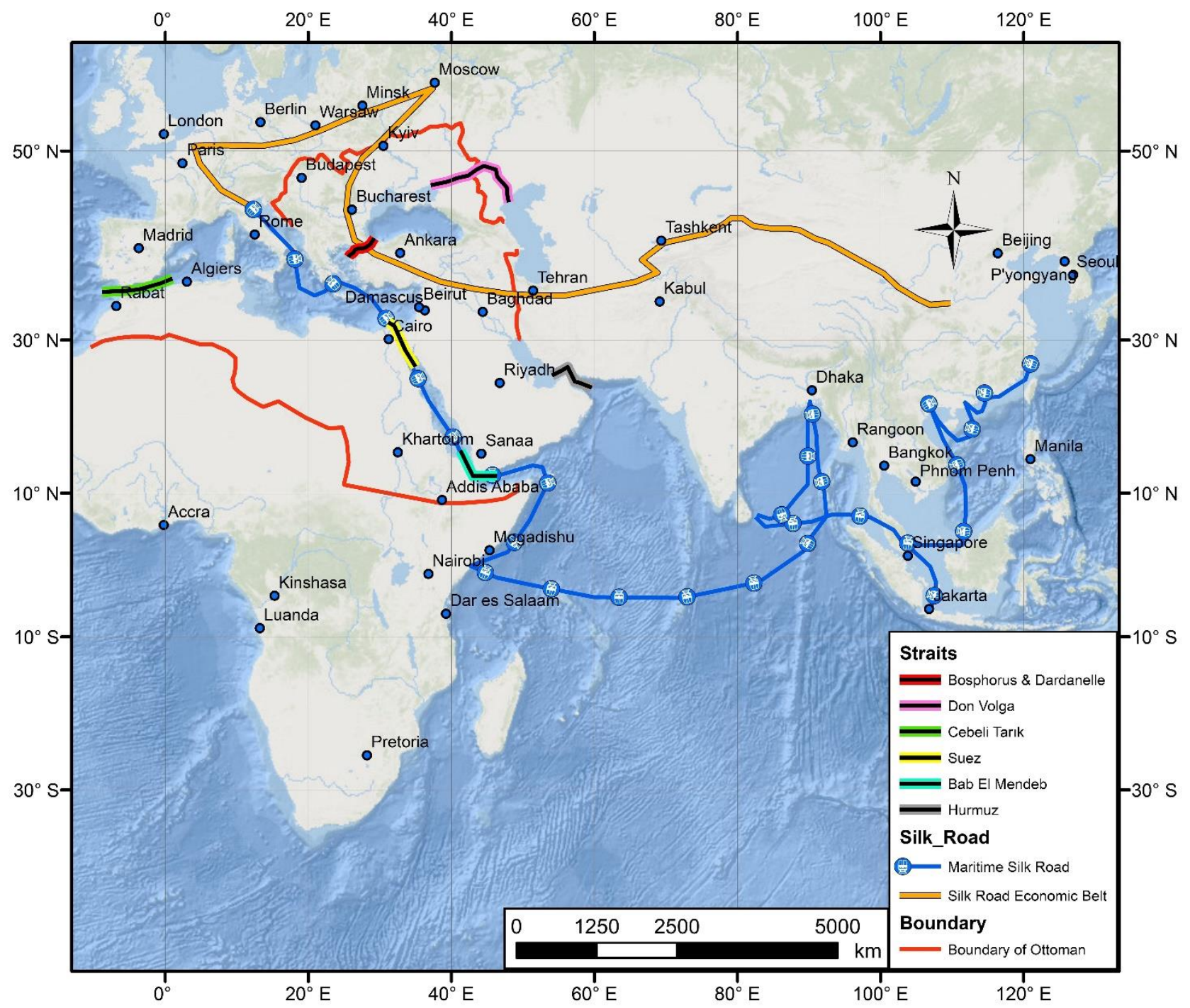

Figure 8. Geostrategic importance of straits -- Bosphorus and Dardanelles -

The waterway through Bosphorus and Dardanelles is the only passage for transits between Black Sea and Mediterranean Sea and thus overseas, with the numbers of vessels transiting 41103 and 43999 and the volume of transits $613088166 \mathrm{gt}$ and $849140218 \mathrm{gt}$, respectively for 2018 [15]. Transits in addition to inner city ferryboats and tours --2500 in a day-- between two sides of Istanbul --Asia and Europe-- create massive traffic volume, risking the safety of Istanbul. On this truth, the prime minister of the time started a campaign for a Canal dividing the city second time but with an artificial waterway. A majority of public has called the campaign as The Crazy Project.
Launching the Campaign on Canal Istanbul on April 27, 2011, Turkey Prime Minister expressed the idea of building a new canal that will safeguard Istanbul from ship accidents. Creating new cities, harbors, marinas, the project has arguably a great potential to contribute to the economy of Istanbul as well as of Turkey. It has been receiving wide public reactions in a short time. Its expected cost, its feasibility, its state of regulatory compliance, its environmental impacts have been being discussed by people. Together with changing details depending on the progress in the processes, the cost of the project is changing. Contrary to initial estimations of 20 to 80 billion dollar 
argued by different organizations through media, The Ministry of Environment an Urbanization declared on October, 2019 that the cost of the project revised to 75 billion TL (12.74 billion \$) from the previous declared cost -- 60 billion TL--. (10.18 billion $\$$ ). Identification of the extent of the project accounts for the difference between cost estimations. 75 billion TL seems only for the Canal and its facilities while constructing cites looks more beyond this budget.

Revenue estimations for the project is also questionable. Estimations runs up around 10 billion $\$$ per year, while there is a strong argument that any income from transits through Canal Istanbul is not possible due to Montreux Convention. Montreux imposes no charge or taxes to be levied by Turkish authorities except for sanitary controls, light and channel buoys and lifesaving services. Note that Montreux allows charging a one-way fee for the services unless a voyage takes no longer than six months.

There is no publicly available revenue data for Turkish Straits. Nonetheless, average potential revenues from Canal Istanbul, which is to bypass Bosphorus, and Canal Marmara, which is to bypass Dardanelles, may be estimated by means of shipping statistics. Accordingly, using the numbers and tonnages of transits provided by The Ministry of Transportation and Infrastructure and Suez Canal Authority [12,13], revenue estimations were made for the vessel traffic of 2017 --before the pandemic--. Revenues of Bosphorus and Dardanelles were estimated based on the service fees in accordance with Montreux Convention, for different directions of navigation as well as for the assumptions of Turkish and foreign flag vessels [16,17].

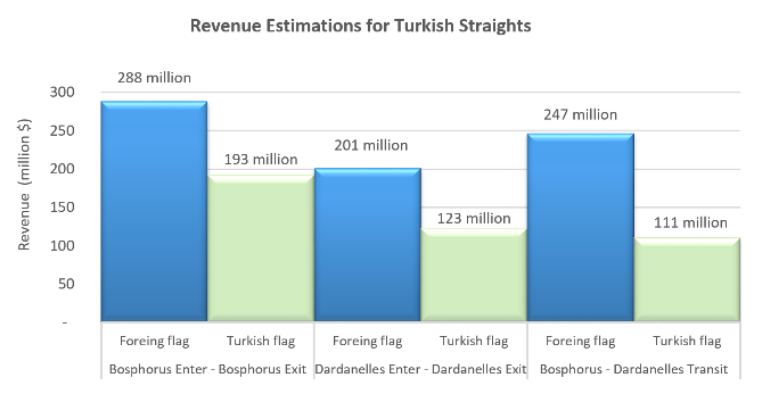

Figure 9. Revenue estimations for Turkish straits.

Figure 9 indicates that total maximum revenue for the observed vessel traffic is possible for a Bosphorus EnterBosphorus Exit Navigation. When calculations are implemented for transits throughout the route of Bosphorus-Marmara-Dardanelles, estimated revenues are about 111 million $\$$ for the assumption of Turkish flag vessels and 247 million \$ for the assumption of foreign flag vessels, regarding a one-way traffic, which is allowed to charge by Montreux Convention.

Contrary to transits through the straits --Bosporus and Dardanelles--, Canal Istanbul as well as anticipated Canal
Marmara may apply different charges at international rates, ignoring Montreux Convention based difficulties on diverting the ship traffic of Bosphorus into Canal Istanbul and the ship traffic of Dardanelles into Canal Marmara. Based on the shipping statistics of Bosphorus and Dardanelles [12,15] and using the tariff of Suez Canal for transits [13], the potential revenue from the canals --Canal Istanbul and Canal Marmara-- were calculated. Revenue of Suez Canal was calculated based on the shipping statistics and Tariff of Suez Canal $[13,18]$. Revenue estimations are compared in Figure 10

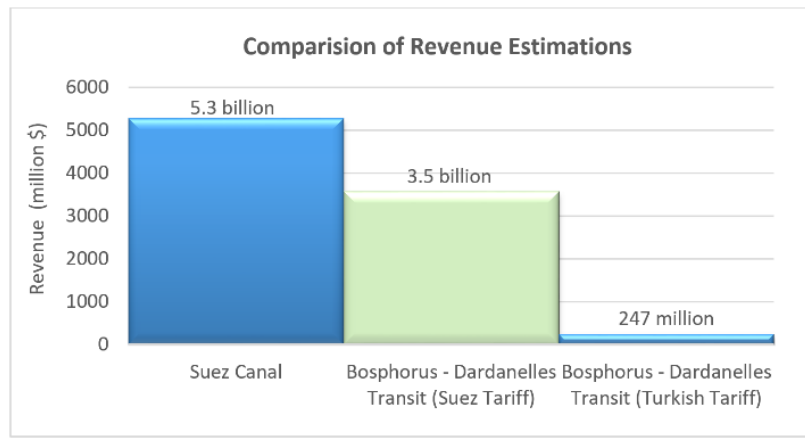

Figure 10. Revenue estimations for transits through Bosphorus-Marmara-Dardanelles.

Figure 10 shows potential revenues from the Canals, in comparison with the straits. Estimated revenue for transits through Canals (i.e. the route of Canal Istanbul, Marmara, Canal Marmara) is 3.5 billion \$, when Suez tariff is applied. Contrary to one-way pricing applied for the straits, two canal pricing and/or two-way pricing may theoretically be applied for the Canals, so as to double and/or quadruple charges of transits, if vessels could be diverted to the canals instead of the straits. Provided that the target cost -- 75 billion TL (12.74 billion \$) -- of The Ministry of Transportation and Infrastructure is attained, Canal Istanbul Project is likely to be profitable and return its investment in several years. This would prompt a Canal on Gallipoli -Canal Marmara-- which would cost only $15 \%$ of Canal Istanbul. However, the provision of Montreux Convention conditions the successes of all these economic scenarios.

\section{Legal Aspect of Canal Istanbul}

The regime of transits through Turkish Straits is regulated by Montreux Convention, signed on July 1936. There is a freedom of transit and navigation without any formalities, charge or tax, in accordance with the convention [19]. However, there are some limitations for War ships during peace and war times for Black Sea and Non-Black Sea Powers.

For merchant vessels, in time of peace, a complete freedom of transit and navigation in the straits is provided, by day and by night, under any flag with any kind of cargo. The only tax and charge to be levied by Turkish government are for a) Sanitary control stations b) Lighthouses, light and 
channel buoys and c) Lifesaving services [19]. Accordingly, the total applicable charge for each ton of net register tonnage is 0.075 Francs gold for sanitary control stations, 0.42 Francs gold (below 800 tons) and 0.21 Francs gold (above 800 tons) for lighthouses, light and channel buoys and 0.1 Francs gold for life saving services [19]. These shall apply in respect of a return voyage through straits --either only for a voyage of Dardanelles-MarmaraBosphorus or for a voyage of Bosphorus-MarmaraDardanelles.

Despite the fact that the charges above are in Francs gold, a fixed exchange rate was applied for years [20]. Therefore, the revenues of straits decreased dramatically. In 1983, as a substitute of Francs gold -- $0.290322 \mathrm{~g}$ fine gold--, the exchange rate between gold and USD - $1 \mathrm{~g}$ gold $=2.78$ USD-- is used for charging transits, upon a secret ministerial decision No. 6138. However, such a tariff could be applied only with $75 \%$ discount, as a result of international political pressures [20]. Today's value of $1 \mathrm{~g}$ fine gold is around 47.5 USD. This corresponds to 17 times lost in revenue.

In time of war, If Turkey is belligerent, merchant vessels not belonging to countries at war shall enjoy freedom of transit and navigation unless assisting enemy [19].

For war vessels, in time of peace, light surface vessels, minor war vessels and auxiliary vessels belonging both Black Sea and non-Black Sea Powers have a freedom of transit through straits without paying any taxes or charges, provided that a prior notification is given to Turkish Government by diplomatic channel 8 days earlier than a transit for Black Sea Powers and 15 days earlier than a transit for Black Sea Powers. Transits should begin daytime [19]. Capital ships of black Sea powers with high tonnages may pass through straits on condition of singly escorted not more than two destroyers [19]. Submarines of these powers must pass straits singly and, on the surface, and travel by day [19]. Total tonnage of all foreign naval forces transiting in straits shall not exceed 15000 tons and not comprise more than 9 vessels [19]. Any aircraft carried on these vessels shall not be used in no circumstance [19]. Total tonnage of Non-Black Sea Powers in Black Sea shall not exceed 30000 tons. However, this limit shall be increased by the same amount up to 45000 tons if the tonnage of the strongest fleet in the Black Sea exceeds by at least 10000 tons the tonnage of the strongest fleet in that sea at the date of signature. Total tonnages of Non-Black Sea powers to be in Black Sea shall be lower than two-thirds of this limit. War vessels of Non-Black Sea Powers shall remain in Black Sea less than 21 days [19].

In time of war, If Turkey is not belligerent, warships have a freedom of transit and navigation through straits, under the same conditions as in time of peace. However, vessels of belligerent powers shall not pass through straits. [19]. If Turkey is belligerent, passage of warships is entirely left to discretion of Turkish Government [19]. During an imminent war threat, Turkey may also apply his decision on passage [19].
For civil aircrafts, upon a prior notification, Turkish government will indicate available air routes between Black Sea and Mediterranean Sea, outside of the forbidden zones to be established in straits [19].

The most controversial consequence of the convention arises for non-riparian super powers of the world [21]. They are not able to pass through straits due to the weight limitations of the conventions. Especially, aircraft carriers, submarines, and other high tonnage war vessels are not able to use straits in accordance with the convention. The 21-day time limitation is the other disputed issue for non-riparian countries.

The convention intends to remain in force for 20 years, however, the principle of the freedom of transit and navigation is presumed to continue without limit of time. It would and will continue in force until two years of any notification of denunciation by contracting parties [19]. If upon such a notification, Montreux Convention is denounced in accordance with the provision of Article 28, a conference needs to be assembled to conclude of new Convention [19].

\section{Environmental Impacts of the Project}

By Turkish Government, the aim of Canal Istanbul Project is defined as "An alternative Canal Project is planned to protect historical structure of Bosphorus and human life" in the Application Document for Environmental Impact Assessment [11]. It is noted there that "Canal Istanbul Project is not only a transportation project but also includes harbors, marines, islands, coastal earthworks, coastal structures, and others sub and super structures."

The studies implemented by The Ministry of Transportation and Infrastructure to estimate possible environmental impacts of Canal Istanbul are summarized below [11]. These studies are primarily; for clarification of the alignment of the route, determination of socio-economic impacts of the project on logistics and transportation. Field investigations consist of geologic, geo-seismic, hydrogeologic, tsunamic, wave and earthquake related studies as well as marine studies including currents, sediment, temperature, salinity, turbidity and pollution. Model studies consist of hydrodynamic, water quality, ground water and sediment transportation studies.

Due to the fact that all these studies have been being implemented, disputes over environmental concerns are never ending. Argument of these concerns are mainly related to Canal Istanbul's impacts on hydrology, marine ecology, agriculture, population and city life.

From the hydrologic view, Sazlidere Dam and Terkos (Durusu) Lake are two important fresh water resources laying on the route of the canal. Suppling 3.3\% of water requirement of Istanbul (10\% of those of European-side), Sazlidere Dam is planned to be completely removed by the project. Suppling $3.3 \%$ of water requirement of Istanbul ( $10 \%$ of European-side). Likewise, Terkos Lake is sensitive to salination due to sea water to be diverted inside the Canal Istanbul. It supplies $8.6 \%$ of water requirement of Istanbul 
(25\% of European-side). Groundwater resources are also under the risk of salination. Once groundwater is beginning to salinate due to the intrusion of sea waters, the process of salination cannot be easily stopped. For such a case, the degree of damage may not be estimated accurately even by elaborative field and laboratory studies. Thereafter, next generations may face a risk of loss their source of habitat.

Possible changes that Canal Istanbul may create on marine environment is another problematic issue. Characteristics, currents and level differences of the Black Sea and Marmara Sea are main actors of marine problems. Bosphorus conveys high nutrient, high oxygen, less saline and high-level Black Sea surface waters to the surface of Marmara, while there is a little amount of reverse bottom flows, carrying low nutrient, low oxygen, high salinity and low-level Marmara waters to Black Sea. Same behavior might be expected for the new channel, bottom of which is only $25 \mathrm{~m}$ below from sea surface and is very higher than the bottom of Marmara and Black Seas. Flowing into Marmara Sea, Black Sea surface waters are of high oxygen and get saturated by the absorption of atmospheric oxygen. However, it cannot pass down and mix into Marmara Sea's low level, high dense layer, which is originated from Mediterranean Sea waters. Thus, a deposition of excess amount of nutrient into Marmara Sea by Canal Istanbul would bring production of microorganism, organic matter, depletion of oxygen and finally organic decomposition and demineralization. This process will be believed to lead the low level high dense layer of Marmara to fully oxygen depleted. Although there is little amount of bottom flows pushed backward to Black Sea through Bosphorus and there are some mixing between upper and lower layers of Marmara Sea due to the water jet of Bosphorus, Canal Istanbul would increase depression on Marmara Sea. It is considered that Marmara would eventually have offensive sewage-like odor. Nonetheless, it is not easy to estimate full effects of Canal Istanbul flows into Kucukcekmece Lake, Marmara Sea, Marmara currents and aquatic life.

The project will bring population growth around region, creating a center of attraction. Considering high populated impermeable land surface of Istanbul, it has a potential to create a concrete jungle, if the processes cannot be managed properly [22]. According to last declarations from the Ministry of Environment and Urbanization, such a danger is foreseen so that planned cites will be low story and less populated (500 thousands which is far lower than the previously declared 1.2 million). Nonetheless, new cities mean new highways, bridges, impermeable areas and degradation of agricultural areas and water basins.

The size of the construction is so high as to affect the city life. The construction of the canal will divide European Site of Istanbul into an isolated island and a peninsula. Heavy traffic will continue around the construction over at least 4 years. 1 billion $\mathrm{m} 3$ earthwork is roughly 25000 trucks in a day. Environmental impacts of such a traffic on emissions of aerosols, fumes, noise, odour, dust etc. seems to be extreme. Cancelation of earth fill islands seems reasonable regarding construction pollution on Marmara Sea and traffic to be created in highly populated Kucukcekmece.

\section{Results and Discussion}

Istanbul is in a strategic location connecting Black Sea to international waterways through Cebelitarı (Gibraltar), Suez and Bab El Mendep. Istanbul is also in a key location for Silk Road Economic Belt and Maritime Silk Road initiatives, aiming to revive international trade from/to Asia to/from Europe and world. Bosphorus, the strait diving Istanbul into two parts --European and Anatolian sides -controls maritime transportation of Black Sea. Dardanelles is Turkey's other important strait, providing passage for vessels coming from Black Sea and going to Aegean Sea and then Mediterranean Seas. Main problem bringing Canal Istanbul into attention of Turkish Government is the safety of Istanbul for ship transits. It is expected that Canal Istanbul relieves the traffic on Bosphorus and protect Istanbul from ship accidents, ensuring new facilities such as harbors, marines, islands, coastal earthworks, coastal structures and two smart cities.

From safety aspect, the project provides an alternative sea passage between Black Sea and Marmara Sea. It keeps Istanbul safe from ship accidents and returns its investment in a several years, which sounds plausible. Building a new and safe international sea passage would be a future vision of the country, enhancing infrastructure via smart cities and other facilities. However, complications originated from international laws and conventions and potential environmental impacts make things sophisticated.

Navigation through the straits is regulated by Montreux Convention. Recognized by all contracting parties, the convention stands upon the principle of freedom of transits and navigation through the straits. The success of the Canal Istanbul relies therefore on if ships can be diverted to Canal Istanbul. The one way of doing this is denunciation or amendment of Montreux Convention. If a denunciation would be the case, a conference needs to be assembled to conclude a new convention [19]. If a proposal for amending some provisions of the convention would be suggested, it should be done at the end of each five-year period from the registration of the convection [19]. Montreux Convention would remain in force for 20 years. However, it is still in force since no High Contracting Party have given any notice of denunciation [19]. On a conference to be assembled upon such a notice, new problems may arise for the freedom of transits of merchant and war vessels. It is possible to see new parties willing to participate to this conference, especially world's leading powers of Non-Black Sea countries. Negotiations therein may potentially create new conflicts among leading Powers and Black Sea countries. However, there is somehow always chance to find a solution, with consents of all parties, if the negotiations can be managed successfully.

The spokesman of Turkish presidency declared in December 2019 that "Canal Istanbul is not a project to revoke Montreux Convention. Straits are under the Authorization of Turkey, in respect of Montreux Convention and inside our geography", however public sensation on the future of the convention is still alive. 
Montreux Convention grants merchant vessels to enjoy complete freedom of transit and navigation, except merchant vessels of the countries that are not at war with Turkey [19]. It allows charging them for some service fees, only for one direction. It might be possible make an adjustment for transits, by updating the value of French gold to today's rate (from its 1983's value to Today's value). This will neither violate nor need denunciation or amendment the convention, but increase 17 times of revenues from transits. Montreux Convention have some weight and time limitations for the transits of warships of Non-Black Sea Powers [19]. Beyond these limits, during peace, Turkey has no practical control over war vessels. During war, if Turkey is belligerent, all vessels or, if else, the vessels belonging to belligerent powers may not pass through the straits, depending on Turkey's consent [19].

In fact, Montreux Convention comprises all of Bosphorus, Dardanelles and Black Sea, so that Canal Istanbul will not provide a full maritime control over transits and navigation. Strictly speaking, a one more canal on Gallipoli --Canal Marmara-- is needed to have a maritime control over transits along Aegean Sea to Black Sea. As long as Montreux Convention is in force, the control provided only by Canal Istanbul will be a Gallipoli bounded control, for which minimum criteria suggested by Montreux Convention must be satisfied through the route of Dardanelles-Marmara Sea- Bosphorus. Transits and navigation above the limits of the convention may be then diverted to Canal Istanbul. Therefore, Canal Istanbul may primarily affect the time and somehow weight limitations of foreign naval forces to be in Black Sea [19], since there is a freedom of transit and navigation for merchant vessels [19]. On the other hand, a full control above the limits of Montreux Convention may be provided only by the route of Canal Marmara- Marmara Sea-Black Sea, upon construction of Canal Marmara as a next step of Canal Istanbul.

If Montreux Convention will expire at the cost of international conflicts, there will be no practical advantage of such an artificial canal -- Canal Istanbul and Canal Marmara--, on controlling transits and navigation, but on reducing shipping traffics in the straits. On other hand, if Montreux Convention will be in force after the construction of Canal Istanbul and anticipated Canal Marmara, different charges may then be applied for different routes. In such a case, Dardanelles-Marmara Sea-Bosphorus would be charged in accordance with Montreux but by an updated exchange rate. Canal Marmara-Marmara Sea-Canal Istanbul route (or Dardanelles-Marmara Sea- Canal Istanbul route, if only Canal Istanbul is constructed) would charge for lower rates than those of the updated DardanellesMarmara Sea-Bosphorus rates, thus navigation may be diverted to outside of Bosphorus and Dardanelles (or outside of Bosphorus if only Canal Istanbul is constructed). Canal Marmara may cost less than $15 \%$ of Canal Istanbul and have potential to increase/double revenues form transits, depending on the denunciation or amending of Montreux Convention.

Considering all these uncertainties, possible scenarios for the future of transits and navigation through Turkish straits and prospective canals are summarized in Table 3, based on control over transits, investment, revenue, and environmental impacts. Details on estimations and assumptions are given in Section 3.

Evaluation of these scenarios assures that the success of the project will be driven by political decisions on financial model to be used, future of Montreux Convention and environmental impacts of the project. President Erdogan declared in his meeting on 27 December 2019 that Canal Istanbul will be done, regardless of "if you want it or not!" while the Mayor of Istanbul informed that Municipality of Istanbul renounce the protocol of Canal Istanbul, emphasizing if Canal? or Istanbul? Accordingly, Should Canal Istanbul Project need to be constructed, its environmental impacts must be minimized to leave a livable city for next generations. Effective solutions should be suggested especially for the sustainability of water resources, the protection of aquatic and terrestrial life, the prevention of farmland degradation and environmental pollution. Population growth and traffic increase should be kept limited.

Water resources on the historical peninsula is limited, having clean fresh water is getting more difficult day by day. Therefore, Canal Istanbul Project will bring a new stress on City's water demand, by removing Sazlidere Dam, which supplies $10 \%$ of the water requirement of the European side of Istanbul, and by risking to salinate the waters of Terkos Lake, which supplies $25 \%$ of the water requirement of the European side. 65 percent of Istanbul's population lives in Europe, but most of the closest fresh water resources available is in Anatolia, specifically in Melen Stream, $190 \mathrm{~km}$ far from the European side.

Changes of Marmara Sea's surface and bottom currents should be well studied, to protect aquatic life and sea environment. The flows into or out of Marmara through Canal or Canals should be examined so as to protect flora and fauna and thus to keep ecological balance of Marmara Sea. Exclusion of Marmara Islands from the Project will reduce environmental pressures on Istanbul as well as the cost of the project. Upgrade or development of new ports may improve logistics.

Smart cities to be constructed should be evaluated in unity with the rest of the Istanbul so as to transform older settlements. Without collaboration with Municipality of Istanbul, such smart cities seem to be problematic to build. They should be evaluated in a way to keep Istanbul green, livable, accessible. Pollutions and heavy traffic driven by the construction should be minimized and controlled. Finance model of the construction is another problem that needs to be solved. 
Table 3. Scenarios for the future of straits.

\begin{tabular}{|c|c|c|c|c|c|c|c|c|c|}
\hline 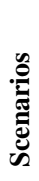 & $\stackrel{\stackrel{\Xi}{\Xi}}{\check{\Xi}}$ & 氖 & & & $\begin{array}{l}\text { Control over } \\
\text { straits }\end{array}$ & 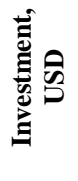 & 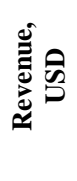 & \begin{tabular}{|c|} 
Shipping \\
Safety \& \\
Environmental \\
Concerns
\end{tabular} & Explanation \\
\hline \multirow{4}{*}{ - } & \multirow{4}{*}{ 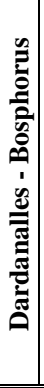 } & \multirow{4}{*}{$\underset{\stackrel{0}{0}}{\stackrel{0}{\Xi}}$} & \multirow{2}{*}{ 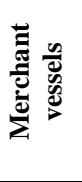 } & Peace time & $\begin{array}{l}\text { In accordance with Montreux } \\
\text { (No control) }\end{array}$ & \multirow{4}{*}{$\stackrel{\stackrel{0}{N}}{N}$} & \multirow{4}{*}{ 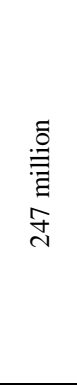 } & \multirow{4}{*}{$\begin{array}{c}\text { Risk of ship or } \\
\text { tanker accidents } \\
\text { around } \\
\text { Bosphorus. }\end{array}$} & \multirow{4}{*}{$\begin{array}{l}\text { Concerns for } \\
\text { shipping safety } \\
\text { in Bosphorus }\end{array}$} \\
\hline & & & & War time & $\begin{array}{l}\text { In accordance with Montreux } \\
\text { (for vessels of countries at war with } \\
\text { Turkey) }\end{array}$ & & & & \\
\hline & & & \multirow{2}{*}{$\begin{array}{l}\frac{n}{d} \\
\vdots \\
2\end{array}$} & Peace time & $\begin{array}{l}\text { In accordance with Montreux) } \\
\text { (Tonnage and time limitations }\end{array}$ & & & & \\
\hline & & & & War time & $\begin{array}{l}\text { In accordance with Montreux } \\
\text { (Same as peace time, If Turkey is not in } \\
\text { war; Full control, If Turkey is in war) }\end{array}$ & & & & \\
\hline \multirow{4}{*}{$\sim$} & \multirow{4}{*}{ 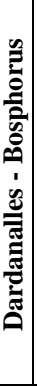 } & \multirow{4}{*}{ 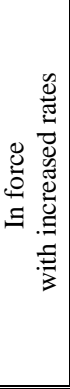 } & \multirow{2}{*}{ 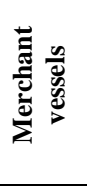 } & Peace time & $\begin{array}{l}\text { In accordance with Montreux } \\
\text { (No control) }\end{array}$ & \multirow{4}{*}{$\stackrel{\circ}{N}$} & \multirow{4}{*}{ 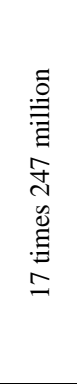 } & \multirow{4}{*}{$\begin{array}{c}\text { Risk of ship or } \\
\text { tanker accidents } \\
\text { around } \\
\text { Bosphorus }\end{array} \mid$} & \multirow{4}{*}{$\begin{array}{c}\text { Possible } \\
\text { international } \\
\text { pressures } \\
\text { for a few years }\end{array}$} \\
\hline & & & & War time & $\begin{array}{l}\text { In accordance with Montreux } \\
\text { (for vessels of countries at war with } \\
\text { Turkey) }\end{array}$ & & & & \\
\hline & & & \multirow{2}{*}{ 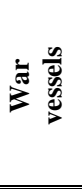 } & Peace time & $\begin{array}{l}\text { In accordance with Montreux) } \\
\text { (Tonnage and time limitations }\end{array}$ & & & & \\
\hline & & & & War time & $\begin{array}{l}\text { In accordance with Montreux } \\
\text { (Same as peace time, If Turkey is not in } \\
\text { war; Full control, If Turkey is in war) }\end{array}$ & & & & \\
\hline \multirow{4}{*}{$m$} & \multirow{4}{*}{ 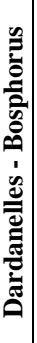 } & \multirow{4}{*}{ 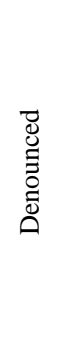 } & \multirow{2}{*}{ 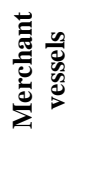 } & Peace time & Not clear & \multirow{4}{*}{ 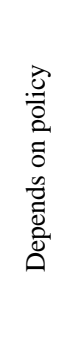 } & \multirow{4}{*}{ 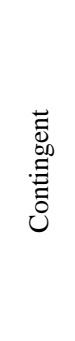 } & \multirow{4}{*}{$\begin{array}{l}\text { Depends on } \\
\text { policy }\end{array}$} & \multirow{4}{*}{$\begin{array}{l}\text { International } \\
\text { conflict }\end{array}$} \\
\hline & & & & War time & Not clear & & & & \\
\hline & & & $\doteqdot \frac{\infty}{E}$ & Peace time & Not clear & & & & \\
\hline & & & & War time & Not clear & & & & \\
\hline \multirow{4}{*}{$\nabla$} & \multirow{4}{*}{ 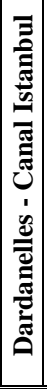 } & \multirow{4}{*}{ 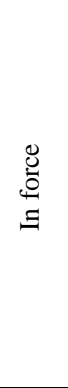 } & \multirow{2}{*}{ 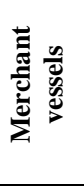 } & Peace time & $\begin{array}{l}\text { In accordance with Montreux } \\
\text { (No Control) }\end{array}$ & \multirow{4}{*}{ 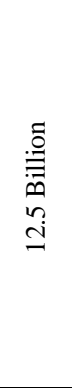 } & \multirow{4}{*}{ 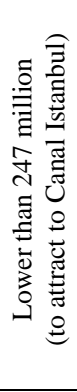 } & \multirow{4}{*}{$\begin{array}{c}\text { Decreased risk } \\
\text { of ship or } \\
\text { tanker accidents } \\
\text { around } \\
\text { Bosporus }\end{array}$} & \multirow{4}{*}{$\begin{array}{l}\text { Governmental } \\
\text { subsidy }\end{array}$} \\
\hline & & & & War time & $\begin{array}{l}\text { In accordance with Montreux } \\
\text { (for vessels of countries at war with } \\
\text { Turkey) }\end{array}$ & & & & \\
\hline & & & $=\frac{\infty}{2}$ & Peace time & $\begin{array}{l}\text { Gallipoli bounded control above the limits } \\
\text { of Montreux }\end{array}$ & & & & \\
\hline & & & $3 \underbrace{\infty}_{0}$ & War time & $\begin{array}{l}\text { Gallipoli bounded control If Turkey is not } \\
\text { in war; } \\
\text { Full control, If Turkey is in war }\end{array}$ & & & & \\
\hline & Ė & & $\ddot{E}$ & Peace time & $\begin{array}{l}\text { In accordance with Montreux } \\
\text { (No control) }\end{array}$ & & & $\begin{array}{l}\text { Low risk of } \\
\text { ship or tanker }\end{array}$ & \\
\hline$n$ & שֶ. & 仓ٕ: & $\sum^{\frac{0}{2}}$ & War time & $\begin{array}{l}\text { In accordance with Montreux } \\
\text { (for vessels of countries at war with } \\
\text { Turkey) }\end{array}$ & $\stackrel{\Xi}{\stackrel{0}{g}}$ & 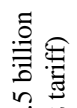 & \begin{tabular}{|} 
accidents \\
around \\
Bosporus.
\end{tabular} & $\begin{array}{l}\text { Low fee and } \\
\text { less formality }\end{array}$ \\
\hline & $\stackrel{\dot{g}}{\bar{g}}$ & $\Xi \underset{\Xi}{\Xi}$ & $=\frac{\infty}{D}$ & Peace time & $\begin{array}{l}\text { Gallipoli bounded control above the limits } \\
\text { of Montreux }\end{array}$ & $\stackrel{n}{n}$ & $\stackrel{n}{\stackrel{0}{=}}$ & $\begin{array}{c}\text { Environmental } \\
\text { problems in }\end{array}$ & $\begin{array}{l}\text { policy to divert } \\
\text { to Canal Istanbul }\end{array}$ \\
\hline & 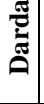 & & $\overrightarrow{0}$ & War time & $\begin{array}{l}\text { Gallipoli bounded control If Turkey is not } \\
\text { in war; } \\
\text { Full control, If Turkey is in war }\end{array}$ & & & $\begin{array}{c}\text { brought by } \\
\text { project }\end{array}$ & \\
\hline
\end{tabular}


Table 3 continue. Scenarios for the future of straits.

\begin{tabular}{|c|c|c|c|c|c|c|c|c|c|}
\hline 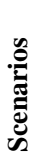 & $\stackrel{\mathscr{O}}{\mathscr{\Xi}}$ & 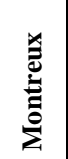 & & & $\begin{array}{l}\text { Control over } \\
\text { straits }\end{array}$ & 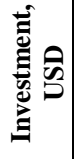 & 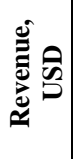 & $\begin{array}{c}\text { Shipping } \\
\text { Safety \& } \\
\text { Environmental } \\
\text { Concerns }\end{array}$ & Explanation \\
\hline \multirow{4}{*}{ b } & \multirow{4}{*}{ 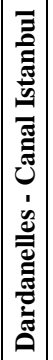 } & \multirow{4}{*}{ 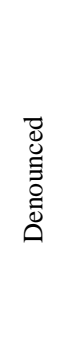 } & \multirow{2}{*}{ 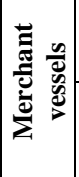 } & Peace time & Not clear & \multirow{4}{*}{ 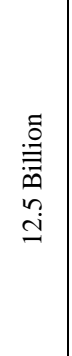 } & \multirow{4}{*}{ 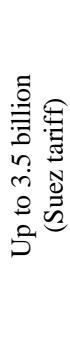 } & \multirow{4}{*}{$\begin{array}{c}\text { No risk of ship or } \\
\text { tanker accidents around } \\
\text { Bosporus } \\
\text { Environmental } \\
\text { problems in Istanbul, } \\
\text { brought by project }\end{array}$} & \multirow{4}{*}{$\begin{array}{l}\text { International } \\
\text { conflict }\end{array}$} \\
\hline & & & & War time & Not clear & & & & \\
\hline & & & \multirow{2}{*}{ 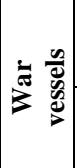 } & Peace time & Not clear & & & & \\
\hline & & & & War time & Not clear & & & & \\
\hline \multirow{4}{*}{$N$} & \multirow{4}{*}{ 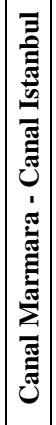 } & \multirow{4}{*}{$\underset{\Xi}{\stackrel{0}{0}}$} & \multirow{2}{*}{ 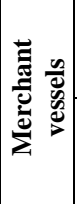 } & Peace time & $\begin{array}{l}\text { In accordance with Montreux } \\
\text { (No Control) }\end{array}$ & \multirow{4}{*}{ 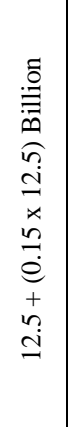 } & \multirow{4}{*}{ 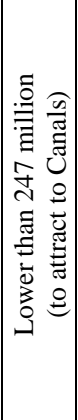 } & \multirow{4}{*}{$\begin{array}{c}\text { Decreased risk of ship } \\
\text { or tanker accidents } \\
\text { around Bosporus and } \\
\text { Gallipoli } \\
\text { Environmental } \\
\text { problems in Istanbul } \\
\text { and Gallipoli, brought } \\
\text { by projects }\end{array}$} & \multirow{4}{*}{$\begin{array}{l}\text { Governmental } \\
\text { subsidy }\end{array}$} \\
\hline & & & & War time & $\begin{array}{l}\text { In accordance with Montreux } \\
\text { (for vessels of countries at war with Turkey ) }\end{array}$ & & & & \\
\hline & & & \multirow{2}{*}{ 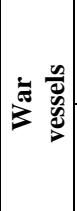 } & Peace time & $\begin{array}{l}\text { Full control above the limits of Montreux, If } \\
\text { Turkey is not in war }\end{array}$ & & & & \\
\hline & & & & War time & $\begin{array}{l}\text { Full control above the limits of Montreux, If } \\
\text { Turkey is not in war; } \\
\text { Full control, If Turkey is in war }\end{array}$ & & & & \\
\hline \multirow{4}{*}{$\infty$} & \multirow{4}{*}{ 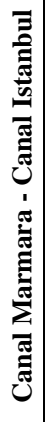 } & \multirow{4}{*}{ 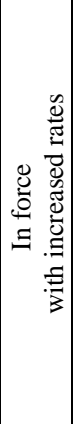 } & \multirow{2}{*}{ 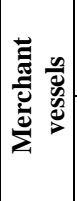 } & Peace time & $\begin{array}{l}\text { In accordance with Montreux } \\
\text { (No Control) }\end{array}$ & \multirow{4}{*}{ 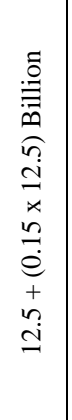 } & \multirow{4}{*}{ 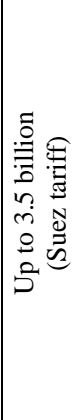 } & \multirow{4}{*}{$\begin{array}{c}\text { Low risk of ship or } \\
\text { tanker accidents around } \\
\text { Bosporus and Gallipoli } \\
\text { Environmental } \\
\text { problems in Istanbul } \\
\text { and Gallipoli, brought } \\
\text { by projects }\end{array}$} & \multirow{4}{*}{$\begin{array}{l}\text { Low fee and } \\
\text { less formality policy } \\
\text { to divert to Canals }\end{array}$} \\
\hline & & & & War time & $\begin{array}{l}\text { In accordance with Montreux } \\
\text { (for vessels of countries at war with Turkey ) }\end{array}$ & & & & \\
\hline & & & \multirow{2}{*}{ 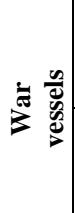 } & Peace time & $\begin{array}{l}\text { Full control above the limits of Montreux, If } \\
\text { Turkey is not in war }\end{array}$ & & & & \\
\hline & & & & War time & $\begin{array}{l}\text { Full control above the limits of Montreux, If } \\
\text { Turkey is not in war; } \\
\text { Full control, If Turkey is in war }\end{array}$ & & & & \\
\hline \multirow{4}{*}{$a$} & \multirow{4}{*}{ 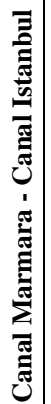 } & \multirow{4}{*}{ 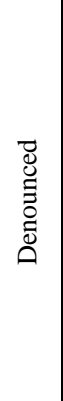 } & \multirow{2}{*}{ 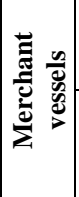 } & Peace time & Not clear & \multirow{4}{*}{ 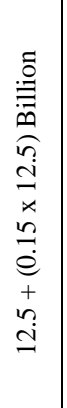 } & \multirow{4}{*}{ 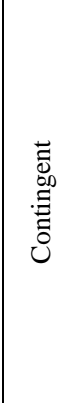 } & \multirow{4}{*}{$\begin{array}{c}\text { Risk of ship or tanker } \\
\text { accidents around } \\
\text { Bosporus and Gallipoli } \\
\text { depending on policy } \\
\text { Environmental } \\
\text { problems in Istanbul } \\
\text { and Gallipoli, brought } \\
\text { by projects }\end{array}$} & \multirow{4}{*}{$\begin{array}{l}\text { International } \\
\text { Conflict }\end{array}$} \\
\hline & & & & War time & Not clear & & & & \\
\hline & & & \multirow{2}{*}{ 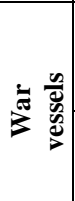 } & Peace time & Not clear & & & & \\
\hline & & & & War time & Not clear & & & & \\
\hline
\end{tabular}

Finally, the future of Canal Istanbul project should be decided in a consensus. This would provide its success. Such huge projects may take years and needs political continuity and decisiveness to complete. In case of any revision on Montreux Convention, an international consensus should be provided without causing any international conflict. The project should be financed in a manner that may not waste public sources, so that an appropriate financial model such as build-operate-transfer and public private collaboration should be determined. All processes should be elaborately inspected throughout the project, regarding environmental concerns. 


\section{Conclusion}

$80 \%$ of world trade is transported via waterways. Turkey is in an important location for International ship traffic, connecting Mediterranean Sea to Black Sea via the route of Dardanelles, Marmara Sea and Bosphorus. Considered with Chinese Marie Time Silkroad projects, Canal Istanbul promises to influence World Dynamics.

Canal Istanbul Project envisages a Bosphorus that is safe for transits and navigation. It aims to preserve historical and cultural heritages of Istanbul, diverting navigation into the Canal to relieve bilateral ferry traffic between two sides of Istanbul. A series of ambiguities related with the content, cost, revenue, environmental impacts, etc. are involved in the declared parts of the project. When environmental problems are ignored or considered to be somehow solved, the main factor leading to Project's goals is the return of investment which is bounded with the control of transits and navigation through the straits. Therefore, the success of the project depends mainly on the future of Montreux Convention which is the main regulatory text for ship traffic on Dardanelles, Marmara Sea and Bosphorus. Forcing navigation toward Canal Istanbul sounds impossible for now, since it needs denouncement or amendment the convention. Alternatively, a lower charge or fast service may be applied in Canal Istanbul for an encouragement to divert the navigation to the Canal. According to the convention, Turkish authorities can levy only some service charge and taxes for transits. However, updating the exchange rate of French gold pegged to the USD in 1983 may be an option that will ensure the charges to increase significantly without changing Montreux Convention, so that a discount charge policy may then be applied for transits through Canal Istanbul. Canal Marmara project which is not on the agenda of the country may thereafter be the further step of Canal Istanbul, allowing full maritime control (over the limits of Montreux) over transits at the cost of additional $15 \%$ of Canal Istanbul.

Depending on the legislative process, contracting methods and environmental policy to be followed, each possible scenario on alternative routes to be created between Aegean Sea and Black Sea will result in different national and international consequences for the control of transits, profitability of canals and sustainability of environmental. From national perspective, two main difficulties emerge. 1) the profitability of the project, which is directly connected to any changes in legislative or administrative procedure currently applied based on Montreux Convention, and 2) environmental concerns that needs to be addressed by a collaborative approach of Municipality of Istanbul and Government. Financial model for construction should not merely rely on public resources. Environmental concerns should be evaluated comprehensively. Sustainability of water resources, sea and terrestrial life should be provided, while keeping the city livable and safe from the dangers of ship transits.

From international perspective, the results of the project may not be limited by not only Black Sea Countries, but also other countries that wish to access to Black Sea via the
Straits or Canals, especially world leading powers. Any changes in the Montreux Convention has a potential to spark a wide scale international conflicts, related to maritime trades and naval forces. Therefore, any regulations related to the transits of both Merchant and war vessels should be prepared by an international consensus, keeping safeguard Turkish straits and intended Canals, and leaving Black Sea in peace without triggering any conflicts throughout region and the world.

\section{Ethics committee approval and conflict of interest statement}

"There is no need to obtain permission from the ethics committee for the article prepared"

"There is no conflict of interest with any person / institution in the article prepared"

\section{References}

[1] UNCTAD 2016, "Review of maritime transport, United Nations", United Nations Conference on Trade and Development, ISBN 978-92-1-112904-5N2016.

[2] Stratejik Plan 2019-2023, “T.C Ulaştırma ve Altyapı Bakanlığı 2019-2023 Stratejik Planı”, Ankara.

[3] Kaya A. Kızıldere M. "Istanbul'daki içme ve kullanma suyu havzalarında arazi kullanımı", TMMOB Çevre Mühendisleri Odası Istanbul Şubesi, Istanbul, 2013.

[4] ISKI 2019, Istanbul Su ve Kanalizasyon İdaresi, www.iski.gov.tr, accessed @ December 2019

[5] Altan T. "Marmara Denizi trafik akışı ve trafik düzeninin analizi", MS Thesis, Sea Transportation Engineering, Istanbul Technique University, Turkey, 2014.

[6] Artuz L. "Marmara ve boğazların ekolojisi ve degisimler", B.Ü. Deniz Teknolojisi Sempozyumu, Su Alt1 Bilim ve Teknoloji Toplantısı, Istanbul, 2003.

[7] Meriç E. Yokeş M. B. Yümün Z. Ü. Eryılmaz M. Eryllmaz F., "Alien benthic foraminifers from turkish strait system", International Journal of Environment and Geoinformatics, 5(1):68- 2018.

[8] Inan Y., "The current regime of turkish straits journal of international affairs", 11-1, 2011.

[9] Ekotrent 2019; Kanal Istanbul Projesi Nedir?, http://ekonomi.haber7.com/, accessed @ December 2019.

[10] Yildız D, "Karadeniz santrancında en stratejik hamle Kanal Istanbul”, Ankara, 2018.

[11] KIPÇED 2017, "Kanal Istanbul Projesi Çevresel Etki Değerlendirmesi Başvuru Dosyası", Ulaştırma, Denizcilik ve Haberleşme Bakanlığı Alt Yap1 Yatırımları Genel Müdürlüğü, Çınar Mühendislik, 2017. 
[12] UDHB 2018, "The ministry of transportation and infrastructure, shipping transit statistics", https://atlantis.udhb.gov.tr/istatistik/gemi_gecis.aspx, accessed@June 2019.

[13] SCNS 2018, "Suez Canal Authority, Suez Canal Navigation Statistics", https://www.suezcanal.gov.eg/English/Navigation/Pa ges/NavigationStatistics.aspx, accessed @ June 2018.

[14] WST 2019, "Word Sea Trades ISL2019”, Shipping Statistics and Market Review.

[15] DTİ 2018, “Deniz Ticareti İstatistikleri 2018, Deniz Taşıtları, Denizyolu Taşıma ve Teşvik İstatistikleri”, T.C. Ulaştırma Denizcilik ve Haberleşme Bakanlığı Deniz Ticareti Genel Müdürlüğü, http://www.denizticareti.gov.tr/, Ankara.

[16] CTS 2019, "Calculater Turkish Straits", https://lethagencies.com/turkish-straits/calculatorturkish-straits, Accessed June@ 2019

[17] KGM 2019, "Fener ve Tahlisiye Ücreti Hesaplayıcı", Kıy1 Emniyeti Genel Müdürlüğü, https://www.kiyiemniyeti.gov.tr/fener_ve_tahsiliye_ ucreti_hesaplayici, accesed @ July 2019
[18] SCR, 2018, "Egypt Maritime Transport: Suez Canal Revenues: Annual", Suez Canal Authority, https://www.ceicdata.com/en/egypt/maritimetransport-revenues/maritime-transport-suez-canalrevenues-annual, accessed @ July 2019

[19] Montreux Convention 1936, Convention Regarding the Regime of Straits Signed at Montreux, July 20.

[20] Yayic1 C. "An assessment on the implementation of gold franc in the framework of montreux convention", Bilge Strateji, Vol 5, No 8, 149-167. 2013.

[21] Akkaya M. A., "Canal Istanbul project and the effect of our relationship with the montreux convention in coastal states of black sea, OUSBAD”, Türk Deniz Ticareti Sempozyumu VII: Karadeniz Limanları Sempozyumu, Ordu, 2015.

[22] Geymen A. Baz I., "Monitoring urban growth and detecting land cover changes on the Istanbul metroplitan area", TMMOB Harita ve Kadastro Mühendisleri Odası, Ulusal Coğrafi Bilgi Sistemleri Kongresi, September 30-October 2, KTÜ, Trabzon, 2007. 